\title{
PENGARUH VARIASI TEMPERATUR KALSINASI TERHADAP BARIUM M-HEKSAFERIT DIDOPING Zn MENGGUNAKAN FOURIER TRANSFORM INFRA RED
}

\author{
Aris Doyan ${ }^{1}$, Ilham Halik ${ }^{1}$, Susilawati ${ }^{1}$ \\ ${ }^{1}$ Program Studi Magister Pendidikan IPA Program Pascasarjana Universitas Mataram \\ Email: arisdoyan@yahoo.co.id, ilham8halik@gmail.com, susilawati.hambali@yahoo.com
}

\begin{abstract}
Abstrak: Barium M-heksaferit (BaM) merupakan bahan magnet permanen yang tergolong hardmagnetic tetapi tidak sesuai untuk beberapa aplikasi, sehingga perlu dilakukan rekayasa untuk menurunkan sifat kemagnetannya menjadi softmagnetic. Penelitian ini bertujuan untuk mengetahui pengaruh temperatur kalsinasi terhadap barium M-heksaferit didoping Zn menggunakan pengukuran FTIR. Proses sintesis barium M-heksaferit menggunakan metode kopresipitasi dengan memvariasikan konsentrasi dopannya 0,0;0,3;0,6; dan 0,9 serta memvariasikan temperatur kalsinasi $80^{\circ} \mathrm{C}$, $400^{\circ} \mathrm{C}, 600^{\circ} \mathrm{C}$ dan $800^{\circ} \mathrm{C}$. Setelah melakukan proses sintesis selanjutnya dilakukan pengujian sampel menggunakan FTIR (Fourier Transform Infra Red). Penelitian ini telah berhasil melakukan sintesis dengan hasil berupa serbuk barium M-heksaferit berwarna coklat muda hingga coklat tua. Berdasarkan hasil pengujian FTIR didapatkan puncak-puncak pada bilangan gelombang $3447 \mathrm{~cm}^{-1}, 2345 \mathrm{~cm}^{-1}, 1615 \mathrm{~cm}^{-1}, 530 \mathrm{~cm}^{-1}, 470 \mathrm{~cm}^{-1}$ masing-masing mengindikasikan adanya gugus fungsi $\mathrm{O}-\mathrm{H}, \mathrm{Ba}-\mathrm{O}, \mathrm{Fe}-\mathrm{O}$ dan $\mathrm{Zn}-\mathrm{O}$ pada sampel. Puncak yang timbul pada ikatan $\mathrm{O}-\mathrm{H}$ semakin mengecil menandakan bahwa ikatan pada gugus fungsi tersebut semakin melemah atau bahkan hilang. Hasil pengujian FTIR tersebut menyatakan bahwa temperatur kalsinasi sangat berpengaruh pada proses sintesis BaM. Semakin tinggi temperatur kalsinasi, bahan pengotor seperti air dan CO pada barium M-heksaferit semakin berkurang, ini menunjukkan barium M-heksaferit yang dihasilkan dapat digunakan sebagai bahan softmagnetic.
\end{abstract}

Kata Kunci: Barium M-Heksaferite, sintesis, kopresipitasi, magnet, FTIR

\begin{abstract}
Barium M-hexaferrite (BaM) is a permanent magnetic material which is relatively hardmagnetic but it is not appropriate for some applications that need to be engineered to degrade the nature of magnetism to be softmagnetic. This study aims to determine the effect of calcinations temperature on $\mathrm{Zn}$ doped BaM using FTIR measurements. Synthesis of $\mathrm{BaM}$ using coprecipitation method by varying the concentrate of dopan 0,$0 ; 0,3 ; 0,6$; dan 0,9 and varying the calcinations temperature $80^{\circ} \mathrm{C}, 400^{\circ} \mathrm{C}, 600^{\circ} \mathrm{C}$ dan $800^{\circ} \mathrm{C}$. After synthesis of $\mathrm{BaM}$ and than the samples were studied using FTIR (Fourier Transform Infra Red). This study has success to synthesis of BaM and the product is a brown powder. Based on the test result of FTIR has been obtained peaks in wave number $3447 \mathrm{~cm}^{-1}, 2345 \mathrm{~cm}^{-1}, 1615 \mathrm{~cm}^{-1}$, $530 \mathrm{~cm}^{-1}, 470 \mathrm{~cm}^{-1}$ indicated a functional group $\mathrm{O}-\mathrm{H}, \mathrm{Ba}-\mathrm{O}, \mathrm{Fe}-\mathrm{O}$ dan $\mathrm{Zn}-\mathrm{O}$ on the powder sample. The peak on $\mathrm{O}-\mathrm{H}$ shrinking indicates that the bond of functional groups are weakened or even disappear.The result of FTIR said that calcinations temperature has effect to $\mathrm{BaM}$ synthesis process. It is found that water and $\mathrm{CO}$ decrease with increase in calcinations temperature, it is showed the product BaM can be used to softmagnetic.
\end{abstract}

Key Words : Barium M-Hexaferrites, synthesis, coprecipitasi, magnet, FTIR

\section{PENDAHULUAN}

Penelitian sains dan teknologi terus mengalami perkembangan dalam segala aspek baik penggunaan alat maupun bidang kajiannya. Pada akhir dekade ini penelitian bidang IPTEK telah berkembang pada bahan magnetik. Bahan magnetik lebih dipilih karena dapat diaplikasikan dalam banyak hal. Aplikasi bahan magnetik saat ini terus meluas dalam segala bidang, mulai bidang elektronik, transportasi hingga bidang keamanan. Melihat trend tersebut maka bisa diprediksikan bahwa kebutuhan bahan magnetik akan terus bertambah dan berkembang secara pesat. Indonesia tentunya tidak boleh tertinggal dalam perkembangan teknologi dari negara-negara lain, untuk itu perlu dilakukan penelitian pada material tersebut.

Salah satu bahan yang banyak dikembangkan adalah barium M-heksaferit ( $\mathrm{BaM})$. Sifat kemagnetan dari BaM mudah untuk dilakukan rekayasa dalam hal sifat kemagnetannya melalui mekanisme subtitusi ionion metal, sehingga mampu menjangkau rentang kemagnetan dari sifat kemagnetan paling lemah ke sifat kemagnetan yang paling kuat. Dengan adanya sifat magnet pada bahan tersebut, dapat diaplikasikan ke media perekaman, interferensi elektromagnetik, magnetik cairan, perangkat microwave, dan sebagainya [1].

Dalam penelitian ini menggunakan mekanisme substitusi ion-ion yaitu $\mathrm{Zn}$ melalui proses sintesis dengan metode kopresipitasi. Penambahan ion dopan $\mathrm{Zn}$ diharapkan dapat mereduksi sifat magnetik dari barium M-hexaferrit $\mathrm{BaFe}_{12-\mathrm{x}} \mathrm{Zn}_{\mathrm{x}} \mathrm{O}_{19}$, sebagai akibat dari terganggunya arah momen magnet dengan munculnya ion substitusional hingga domainnya menjadi random [2]. Selain itu, kenaikan sifat magnet $\mathrm{BaFe}_{12} \mathrm{O}_{19}$ terkait dengan ukuran butir yang semakin kecil (skala nano) [3]. Tingginya nilai medan koersivitas bisa diturunkan dengan membuat ukuran serbuk (butir) mencapai orde nano. Interaksi antar butir efektif untuk ukuran butir $<380 \mathrm{~nm}$ memberikan implikasi terhadap ketiga sifat kemagnetan dasar yaitu magnetisasi remanen, medan koersivitas, dan produk energi maksimum [4].

Berdasarkan uraian diatas, maka pada penelitian ini dilakukan sintesis barium M-heksaferit menggunakan metode kopresipitasi dan didoping $\mathrm{Zn}$ dengan konsentrasi berbeda-beda yaitu 0,$0 ; 0,3 ; 0,6 ; 0,9$ serta temperatur kalsinasi (pemanasan) yang 
divariasikan pula, $80^{\circ} \mathrm{C}, 400^{\circ} \mathrm{C}, 600^{\circ} \mathrm{C}$ dan $800^{\circ} \mathrm{C}$. Pemilihan variasi konsentrasi dan variasi temperatur kalsinasi berdasarkan hasil penelitian-penelitian sebelumnya sehingga diharapkan pada penelitian ini mendapatkan hasil yang lebih baik dari penelitian sebelumnya.

Saidah [4] mengatakan Fasa barium Mhexaferrite $\mathrm{BaFe}_{11,4} \mathrm{Zn}_{0,6} \mathrm{O}_{19}$ terbesar terdapat pada nilai $\mathrm{pH}=1$ pada temperatur kalsinasi $150^{\circ} \mathrm{C}$ selama 4 jam sebesar 83,98\% mempunyai nilai koersivitas (Hc) sebesar 0,0178T, magnetisasi remanensi sebesar 3,113 emu/gram dan magnetisasi saturasi (Ms) maksimum sebesar 25,50 emu/gram. Komposisi fasa Barium MHeksaferit yang didoping dengan doping $\mathrm{Zn}$ melalui metode kopresipitasi banyak terbentuk pada kalsinasi $1000^{\circ} \mathrm{C}$ selama 4 jam dengan $\mathrm{x}=0,3$ [14]. Komposisi fasa Barium M-Heksaferit yang didoping $\mathrm{Zn}$ dengan melalui metode yang sama banyak terbentuk pada kalsinasi $100^{\circ} \mathrm{C}$ selama 2 jam dengan $\mathrm{x}=0,6$ [5]. Sehingga pada penelitian ini digunakan konsentrasi $\mathrm{x}=$ 0,$0 ; 0,3 ; 0,6$ dan 0,9 .

Penelitian ini bertujuan untuk mensintesis barium M-heksaferit dengan dopan $\mathrm{Zn}$ menggunakan metode kopresipitasi, mengetahui pengaruh temperatur kalsinasi terhadap barium M-heksaferit dan mengetahui hubungan perbedaan konsen-trasi dopan terhadap hasil sintesis barium M-heksaferit. Barium M-heksaferit atau dikenal dengan sebutan $\mathrm{BaM}$ memiliki rumus kimia $\mathrm{BaO} .6 \mathrm{Fe}_{2} \mathrm{O}_{3}\left(\mathrm{BaFe}_{12} \mathrm{O}_{19}\right)$ dan struktur heksagonal yang sesuai dengan space group P 63/mmc. Sel komplek $\mathrm{BaM}$ tersusun atas 2 sistem kristal yaitu struktur kubuspusat-sisi (face-centered-cubic) dan heksagonal mampat (hexagonal-close-packed) [6] . Material yang memiliki sifat ferromagnetik bukan merupakan senyawa, tetapi berupa unsur murni. Biasanya dimiliki oleh logam transisi seperti $\mathrm{Fe}, \mathrm{Co}, \mathrm{Ni}$ dan beberapa logam tanah jarang seperti Nd dan Sm. Ferrimagnetik merupakan senyawa, dimana momen magnetiknya berasal dari atom-atom ataupun ion-ion yang tidak saling menghilangkan secara sempurna [4].

\section{METODE}

Sintesis dilakukan dengan metode kopresipitasi. Bahan dasar yang digunakan dalam penelitian ini seperti $\mathrm{BaCO}_{3}, \mathrm{FeCl}_{3} .6 \mathrm{H}_{2} \mathrm{O}$, dan $\mathrm{ZnCl}_{2}$ dalam bentuk serbuk dengan kemurnian $99,99 \%$. Sintesis BaM yang dilakukan dengan menggunakan variasi $\mathrm{x}=0,0 ; 0,3 ; 0,6$; dan 0,9 dan memvariasikan temperatur kalsinasi $80^{\circ} \mathrm{C}, 400^{\circ} \mathrm{C}, 600^{\circ} \mathrm{C}$ dan $800^{\circ} \mathrm{C}$. Pertama-tama melarutkan $\left(\mathrm{FeCl}_{3} \cdot 6 \mathrm{H}_{2} \mathrm{O}\right)$ dalam $\mathrm{H}_{2} \mathrm{O}$ dengan menggunakan magnetik stierrer selama 30 menit (larutan 1) kemudian melarutkan $\mathrm{BaCO}_{3}$ dalam $\mathrm{HCl}$ menggunakan Hot plate magnetic stirrer pada temperatur $70^{\circ} \mathrm{C}$ (larutan 2) selanjutnya melarutkan serbuk $\mathrm{ZnCl}_{2}$ dalam $\mathrm{H}_{2} \mathrm{O}$ (larutan 3). Semua larutan tersebut, larutan 1, 2, 3 dicam-purkan sambil diaduk selama 30 menit hingga homogen (larutan 4). Agar larutan 4 mengendap maka selanjutnya dititrasi dengan $\mathrm{NH}_{4} \mathrm{OH}$ sampai terjadi pengendapan. Setelah itu larutan 4 dicuci dengan aquades sampai $\mathrm{pH}$ netral. Perkursor dikeringkan dengan temperatur $80^{\circ} \mathrm{C}$ dan digerus hingga lembut dan melakukan pengujian menggunakan FTIR. Selanjutnya prekursor dikalsinasi pada temperatur $80^{\circ} \mathrm{C}, 400^{\circ} \mathrm{C}, 600^{\circ} \mathrm{C}$ dan $800^{\circ} \mathrm{C}$ dengan lama penahanan empat jam. Selanjutnya sampel yang telah dikalsinasi akan diuji menggunakan FTIR.

\section{HASIL DAN PEMBAHASAN}

Pada penelitian ini dilakukan sintesis barium M-heksaferit yang didoping Zn menggunakan metode kopresipitasi. Telah berhasil dilakukan sintesis BaM berupa serbuk. Gambar 2 menunjukkan terjadinya perubahan pada hasil sintesis. Perubahan tersebut didasarkan pada adanya perbedaan warna sampel yang dihasilkan pada temperatur kalsinasi $80^{\circ} \mathrm{C}, 400^{\circ} \mathrm{C}$, $600^{\circ} \mathrm{C}$ dan $800^{\circ} \mathrm{C}$ dan pada konsentrasi dopan yang berbeda-beda pula 0,$0 ; 0,3 ; 0,6$; dan 0,9 .

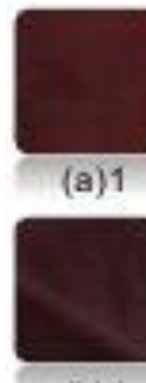

(b) 1

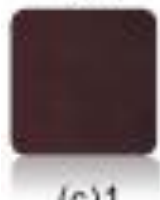

(c) 1

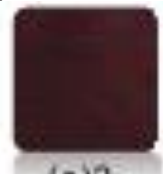

(a) 2

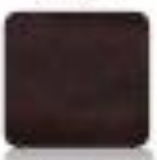

(b) 2

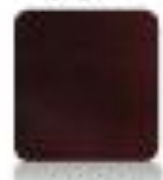

(c) 2
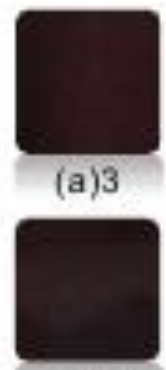

(b) 3

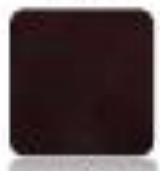

(c)3
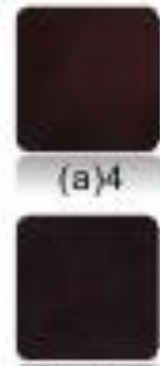

(b) 4

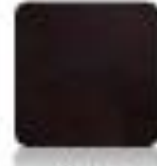

(c) 4
Gambar 1. Perubahan warna sampel (a) konsentrasi $\mathrm{x}=0,3$; (b) konsentrasi $\mathrm{x}=0,6$; (c) konsentrasi $\mathrm{x}=0,9$. (1) $80^{\circ} \mathrm{C}$; (2) $400^{\circ} \mathrm{C}$; (3) $600^{\circ} \mathrm{C}$; (4) $800^{\circ} \mathrm{C}$.

Gambar 1 menunjukkan terjadinya perubahan pada hasil sintesis. Perubahan tersebut didasarkan pada adanya perbedaan warna sampel yang dihasilkan pada temperatur kalsinasi $80^{\circ} \mathrm{C}, 400^{\circ} \mathrm{C}, 600^{\circ} \mathrm{C}$ dan $800^{\circ} \mathrm{C}$ dan pada konsentrasi dopan yang berbeda-beda pula.

Serbuk yang dihasilkan memiliki warna yang berbeda-beda. Perubahan warna pada serbuk tergantung pada konsentrasi pendopingan dan temperatur kalsinasi. Semakin besar konsentrasi pendopingan maka warnanya akan semakin gelap dan semakin tinggi temperatur kalsinasi maka warna serbuk BaM akan semakin gelap.

\section{Karakterisasi Barium M-Heksaferit}

Setelah dilakukan sintesis dan terbentuk serbuk barium M-heksaferit (BaM), selanjutnya melakukan karakterisasi bahan menggunakan FTIR (Fourier Transform Infra Red) yang berguna untuk 
mengetahui gugus ikatan pada sampel serta untuk mengetahui apabila masih ada zat-zat pengotor yang masih tersisa pada sampel BaM. Hasil pengujian dapat dilihat melalui grafik pada gambar berikut.

Berdasarkan gambar 3 bahwa pada besar pendopingan yang sama yaitu $\mathrm{x}=0$ dan temperatur kalsinasi yang berbeda-beda dapat kita ketahui terdapat puncak pada bilangan gelombang 3700-3200 $\mathrm{cm}^{-1}$ mengindikasikan adanya gugus fungsi $\mathrm{O}-\mathrm{H}$ [12]. Terdapat puncak pada bilangan gelombang $3400 \mathrm{~cm}^{-1}$ dan $2347 \mathrm{~cm}^{-1}$. Hasil ini mirip dengan hasil penelitian sebelumnya yaitu pada bilangan gelombang $3352 \mathrm{~cm}^{-1}$, $3640 \mathrm{~cm}^{-1}, 2923 \mathrm{~cm}^{-1}$ dan $2151 \mathrm{~cm}^{-1}$ yang artinya terdapat ikatan O-H [7-9].
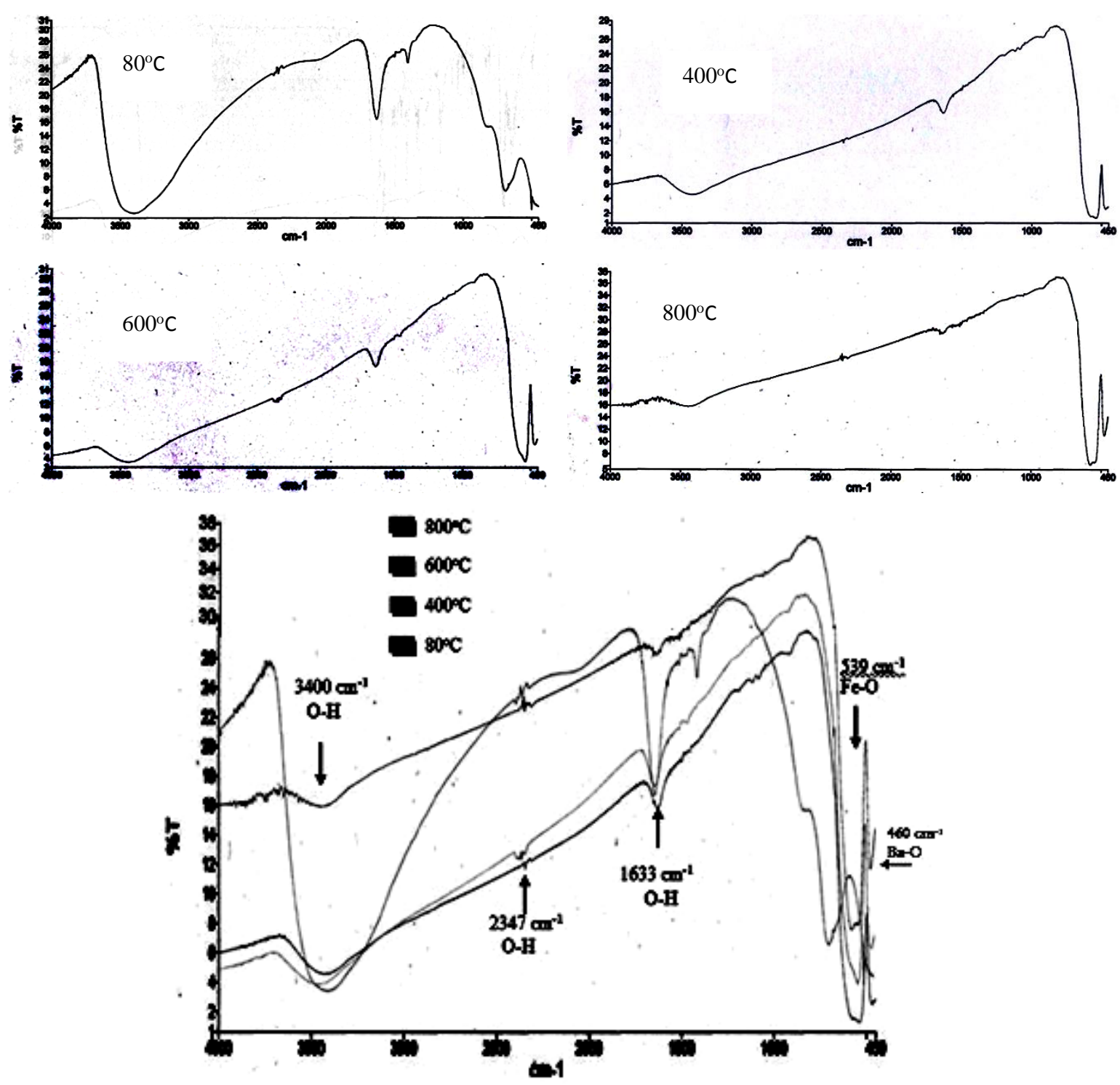

Gambar 3: Grafik pola penyerapan FTIR pada sampel $\mathrm{BaFe}_{12} \mathrm{O}_{19}$ dengan variasi temperatur kalsinasi.

Terdapat puncak pada bilangan gelombang $1633 \mathrm{~cm}^{-1}$, hasil ini serupa dengan penelitian sebelumnya mendapatkan puncak $1628 \mathrm{~cm}^{-1}$ yang mengindikasikan adanya air pada sampel [7]. Sampel tanpa kalsinasi terdapat puncak yang sangat besar dan terus mengalami pengurangan nilai transmisi berbanding terbalik dengan nilai temperatur kalsinasi hingga puncak terkecil terdapat pada kalsinasi $800^{\circ} \mathrm{C}$ yang menandakan pada kalsinasi $800^{\circ} \mathrm{C}$ terdapat air paling sedikit.

Bilangan gelombang kurang dari $1000 \mathrm{~cm}^{-1}$ dikatakan sebagai daerah fingerprint. Pada daerah ini terdapat ikatan metal oxide [7]. Terdapat puncak pada daerah fingerprint tersebut yaitu tepatnya pada 530 $\mathrm{cm}^{-1}, 475 \mathrm{~cm}^{-1}, 460 \mathrm{~cm}^{-1}$, hasil ini serupa dengan hasil penelitian sebelumnya $585 \mathrm{~cm}^{-1}, 546 \mathrm{~cm}^{-1}, 440 \mathrm{~cm}^{-1}$ 
merupakan daerah terdapatnya gugus fungsi $\mathrm{Fe}-\mathrm{O}$ dan Ba-O [10-11].

Pada daerah ini memiliki nilai transmisi berbanding lurus dengan nilai temperatur kalsinasi.
Semakin besar temperatur kalsinasi maka nilai transmisinya juga bertambah [13].

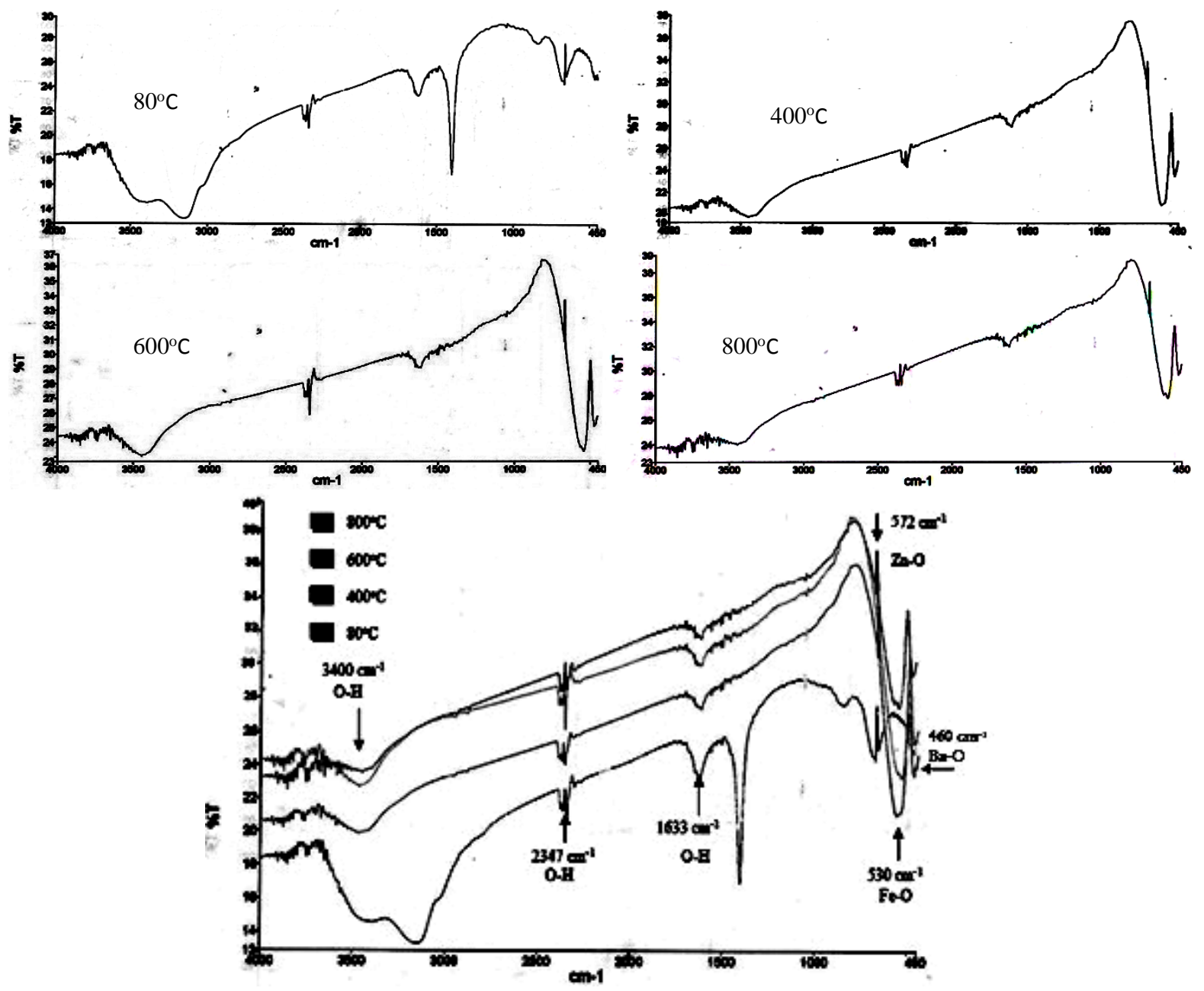

Gambar 4: Grafik pola penyerapan FTIR pada sampel $\mathrm{BaFe}_{11,7} \mathrm{Zn}_{0,3} \mathrm{O}_{19}$ dengan variasi temperatur kalsinasi.

Berdasarkan gambar 4 tersebut bahwa pada besar pendopingan yang sama yaitu $\mathrm{x}=0,3$ dan temperatur kalsinasi yang berbeda-beda dapat kita ketahui terdapat puncak pada bilangan gelombang $3447 \mathrm{~cm}^{-1}$ dan $2345 \mathrm{~cm}^{-1}$. Pada bilangan gelombang $3700-3200 \mathrm{~cm}^{-1}$ mengindikasikan adanya gugus fungsi O-H [12]. Hasil ini mirip dengan hasil penelitian sebelumnya yaitu pada bilangan gelombang $3352 \mathrm{~cm}^{-1}, 3640 \mathrm{~cm}^{-1}, 2923 \mathrm{~cm}^{-1}$ dan $2151 \mathrm{~cm}^{-1}$ yang artinya terdapat ikatan $\mathrm{O}-\mathrm{H}$ [7-9].

Terdapat puncak pada bilangan gelombang $1615 \mathrm{~cm}^{-}$ 1 , hasil ini serupa dengan penelitian sebelumnya mendapatkan puncak $1628 \mathrm{~cm}^{-1}$ yang mengindikasikan adanya air pada sampel [7]. Sampel tanpa kalsinasi terdapat puncak yang sangat besar dan terus mengalami pengurangan nilai transmisi berbanding terbalik. dengan nilai temperatur kalsinasi hingga puncak terkecil terdapat pada kalsinasi $800^{\circ} \mathrm{C}$ yang menandakan pada kalsinasi $800^{\circ} \mathrm{C}$ terdapat air paling sedikit.

Bilangan gelombang kurang dari $1000 \mathrm{~cm}^{-1}$ dikatakan sebagai daerah fingerprint. Pada daerah ini terdapat ikatan metal oxide [7]. Terdapat puncak pada daerah fingerprint tersebut yaitu tepatnya pada $572 \mathrm{~cm}^{-1}$ mengindikasikan adanya ikatan $\mathrm{Zn}-\mathrm{O}$, terdapat juga puncak pada $530 \mathrm{~cm}^{-1}, 475 \mathrm{~cm}^{-1}, 460$ $\mathrm{cm}^{-1}$, hasil ini serupa dengan hasil penelitian sebelumnya $585 \mathrm{~cm}^{-1}, 546 \mathrm{~cm}^{-1}, 440 \mathrm{~cm}^{-1}$ merupakan daerah terdapatnya gugus fungsi $\mathrm{Fe}-\mathrm{O}$ dan $\mathrm{Ba}-\mathrm{O}$ [1011]. Pada daerah ini memiliki nilai transmisi berbanding lurus dengan nilai temperatur kalsinasi. Semakin besar temperatur kalsinasi maka nilai transmisinya juga bertambah [13]. 

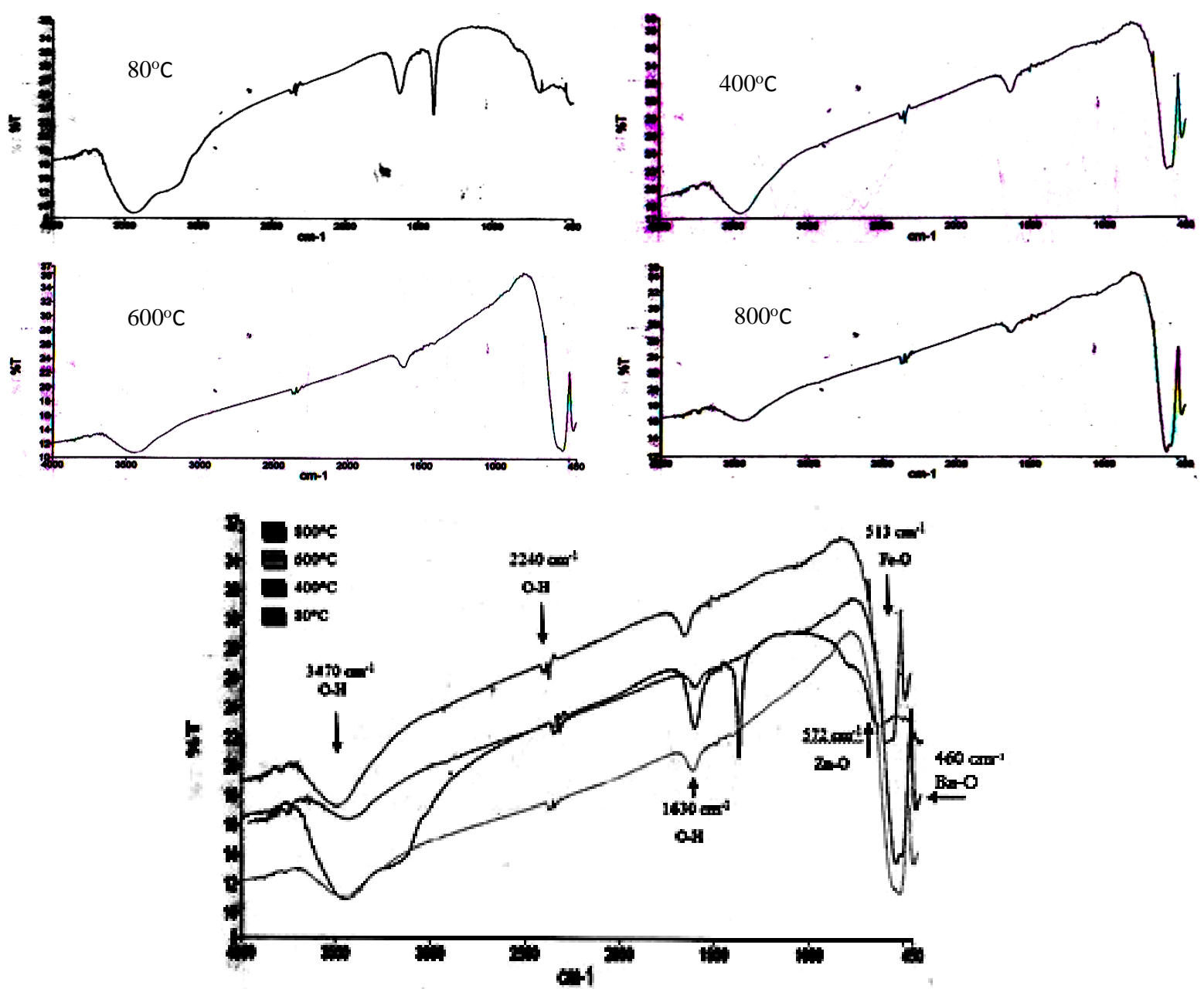

Gambar 5: Grafik pola penyerapan FTIR pada sampel $\mathrm{BaFe}_{11,4} \mathrm{Zn}_{0,6} \mathrm{O}_{19}$ dengan variasi temperatur kalsinasi

Berdasarkan gambar 5 diketahui bahwa pada besar pendopingan yang sama yaitu $\mathrm{x}=0,6$ dan temperatur kalsinasi yang berbeda-beda dapat kita ketahui terdapat puncak pada bilangan gelombang $3447 \mathrm{~cm}^{-1}$ dan $2345 \mathrm{~cm}^{-1}$. Pada bilangan gelombang $3700-3200 \mathrm{~cm}^{-1}$ mengindikasikan adanya gugus fungsi O-H [12]. Hasil ini mirip dengan hasil penelitian sebelumnya yaitu pada bilangan gelombang $3352 \mathrm{~cm}^{-1}, 3640 \mathrm{~cm}^{-1}, 2923 \mathrm{~cm}^{-1}$ dan 2151 $\mathrm{cm}^{-1}$ yang artinya terdapat ikatan $\mathrm{O}-\mathrm{H}$ [7-9].
Terdapat puncak pada bilangan gelombang $1615 \mathrm{~cm}^{-1}$, hasil ini serupa dengan penelitian sebelumnya mendapatkan puncak $1628 \mathrm{~cm}^{-1}$ yang mengindikasikan adanya air pada sampel [7]. Sampel tanpa kalsinasi terdapat puncak yang sangat besar dan terus mengalami pengurangan nilai transmisi berbanding terbalik dengan nilai temperatur kalsinasi hingga puncak terkecil terdapat pada kalsinasi $800^{\circ} \mathrm{C}$ yang menandakan pada kalsinasi $800^{\circ} \mathrm{C}$ terdapat air paling sedikit.

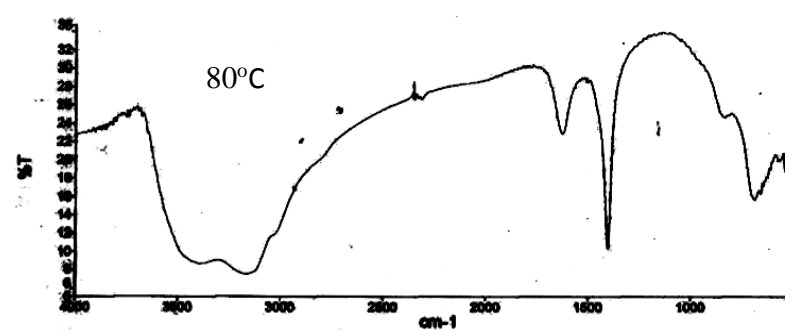

$600^{\circ} \mathrm{C}$

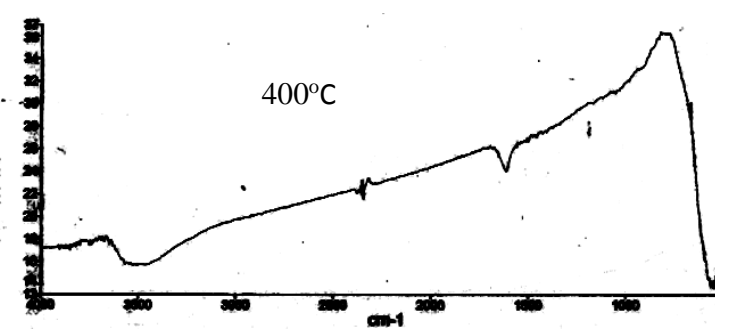

$800^{\circ} \mathrm{C}$ 


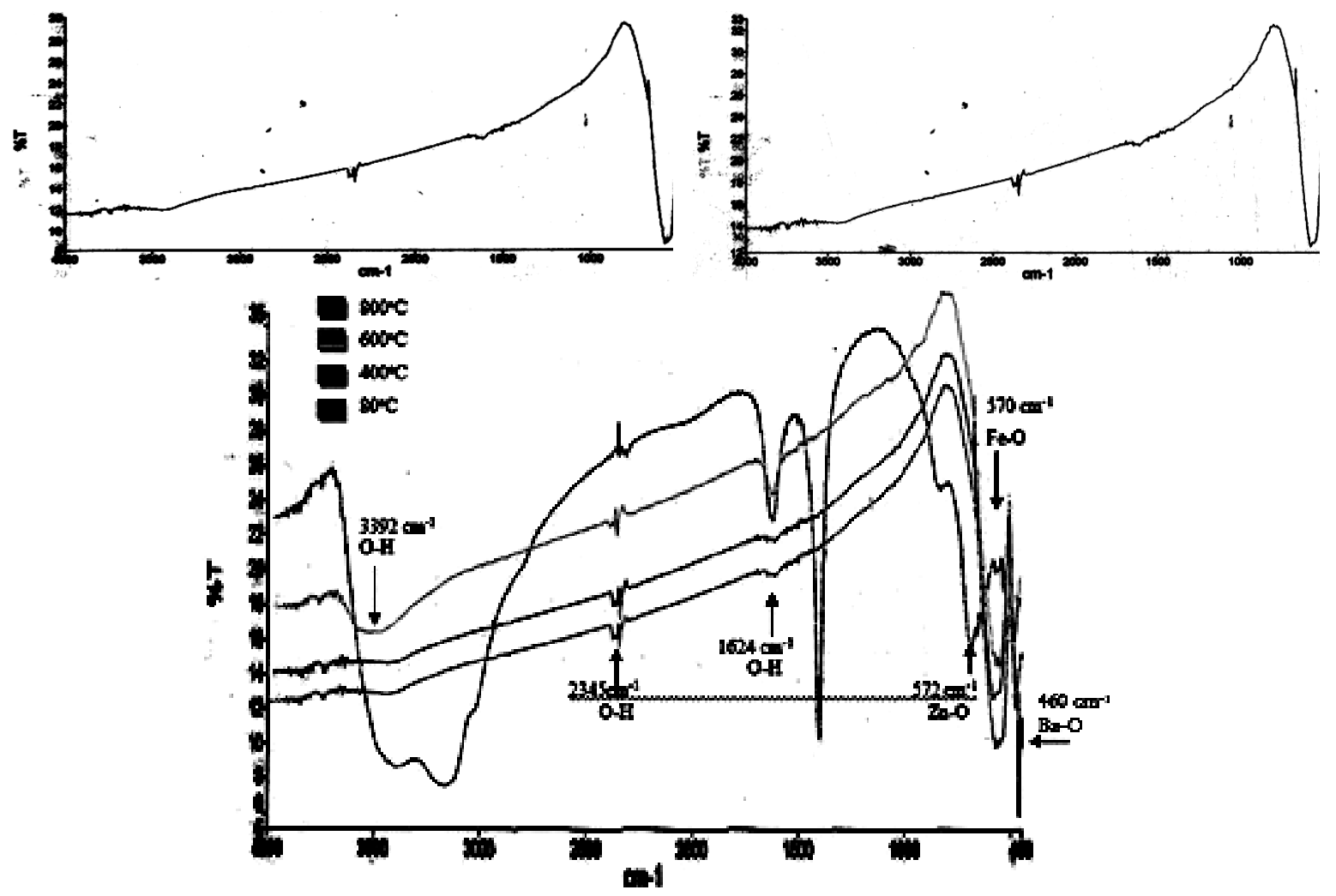

Gambar 6: Grafik pola penyerapan FTIR pada sampel $\mathrm{BaFe}_{11,1} \mathrm{Zn}_{0,9} \mathrm{O}_{19}$ dengan variasi temperatur kalsinasi

Bilangan gelombang kurang dari $1000 \mathrm{~cm}^{-1}$ dikatakan sebagai daerah fingerprint. Pada daerah ini terdapat ikatan metal oxide [7]. Terdapat puncak pada daerah fingerprint tersebut yaitu tepatnya pada 572 $\mathrm{cm}^{-1}$ mengindikasikan adanya ikatan $\mathrm{Zn}-\mathrm{O}$, terdapat juga puncak pada $530 \mathrm{~cm}^{-1}, 475 \mathrm{~cm}^{-1}, 460 \mathrm{~cm}^{-1}$, hasil ini serupa dengan hasil penelitian sebelumnya 585 $\mathrm{cm}^{-1}, \quad 546 \mathrm{~cm}^{-1}, \quad 440 \mathrm{~cm}^{-1}$ merupakan daerah terdapatnya gugus fungsi $\mathrm{Fe}-\mathrm{O}$ dan $\mathrm{Ba}-\mathrm{O}$ [10-11]. Pada daerah ini memiliki nilai transmisi berbanding lurus dengan nilai temperatur kalsinasi. Semakin besar temperatur kalsinasi maka nilai transmisinya juga bertambah [13].

Berdasarkan gambar 6 tersebut bahwa pada besar pendopingan yang sama yaitu $\mathrm{x}=0,9$ dan temperatur kalsinasi yang berbeda-beda dapat kita ketahui terdapat puncak pada bilangan gelombang $3392 \mathrm{~cm}^{-1}$ dan $2345 \mathrm{~cm}^{-1}$. Pada bilangan gelombang $3700-3200 \mathrm{~cm}^{-1}$ mengindikasikan adanya gugus fungsi O-H [12]. Hasil ini mirip dengan hasil penelitian sebelumnya yaitu pada bilangan gelombang $3352 \mathrm{~cm}^{-1}, 3640 \mathrm{~cm}^{-1}, 2923 \mathrm{~cm}^{-1}$ dan 2151 $\mathrm{cm}^{-1}$ yang artinya terdapat ikatan O-H [7-9].

Terdapat puncak pada bilangan gelombang $1651 \mathrm{~cm}^{-1}$, hasil ini serupa dengan penelitian sebelumnya mendapatkan puncak $1628 \mathrm{~cm}^{-1}$ yang mengindikasikan adanya air pada sampel [7]. Sampel tanpa kalsinasi terdapat puncak yang sangat besar dan terus mengalami pengurangan nilai transmisi berbanding terbalik dengan nilai temperatur kalsinasi hingga puncak terkecil terdapat pada kalsinasi $800^{\circ} \mathrm{C}$ yang menandakan pada kalsinasi $800^{\circ} \mathrm{C}$ terdapat air paling sedikit.

Bilangan gelombang kurang dari $1000 \mathrm{~cm}^{-1}$ dikatakan sebagai daerah fingerprint. Pada daerah ini terdapat ikatan metal oxide [7]. Terdapat puncak pada daerah fingerprint tersebut yaitu tepatnya pada 572 $\mathrm{cm}^{-1}$ mengindika-sikan adanya ikatan $\mathrm{Zn}-\mathrm{O}$, terdapat juga puncak pada $530 \mathrm{~cm}^{-1}, 475 \mathrm{~cm}^{-1}, 460 \mathrm{~cm}^{-1}$, hasil ini serupa dengan hasil penelitian sebelumnya 585 $\mathrm{cm}^{-1}, \quad 546 \mathrm{~cm}^{-1}, \quad 440 \mathrm{~cm}^{-1}$ merupakan daerah terdapatnya gugus fungsi $\mathrm{Fe}-\mathrm{O}$ dan $\mathrm{Ba}-\mathrm{O}$ [10-11]. Pada daerah ini memiliki nilai transmisi berbanding lurus dengan nilai temperatur kalsinasi. Semakin besar temperatur kalsinasi maka nilai transmisinya juga bertambah [13].

\section{KESIMPULAN}

Analisis barium M-heksaferit yang didoping dengan variasi $\mathrm{Zn} 0,0 ; 0,3 ; 0,6$ dan 0,9 dengan perubahan temperatur kalsinasi $80^{\circ} \mathrm{C}, 400^{\circ} \mathrm{C}, 600^{\circ} \mathrm{C}$ dan $800^{\circ} \mathrm{C}$ menggunakan FTIR disimpulkan sebagai berikut: Pada serbuk sampel yang didoping $\mathrm{Zn}$ dengan $\mathrm{x}=0,0 ; 0,3 ; 0,6 ; 0,9$ diperoleh gugus ikatan $\mathrm{O}-\mathrm{H}$ pada bilangan gelombang $3400 \mathrm{~cm}^{-1}, 2345 \mathrm{~cm}^{-1}$ dan $1651 \mathrm{~cm}^{-1}$ yang memiliki puncak spektrum semakin mengecil seiring bertambahnya temperatur kalsinasi. Terdapat juga gugus ikatan $\mathrm{Zn}-\mathrm{O}$ pada bilangan gelombang $572 \mathrm{~cm}^{-1}$ yang muncul pada sampel barium M-heksaferit yang telah didoping $\mathrm{Zn}$ 
dan pada bilangan gelombang $530 \mathrm{~cm}^{-1}$ mengindikasikan adanya ikatan Fe-O sedangkan ikatan Ba-O terdapat pada bilangan gelombang $460 \mathrm{~cm}^{-1}$.

\section{UCAPAN TERIMA KASIH}

Kepada semua pihak yang telah membantu sehingga terwujudnya artikel ini dan penelitian ini telah didanai oleh hibah Penelitian Unggulan Perguruan Tinggi (PUPT) Kementrian Ristek dan Perguruan Tinggi Tahun 2015.

\section{DAFTAR PUSTAKA}

[1] Sholihah, F, R., \& Zainuri, M. 2012. Pengaruh Holding Time Kalsinasi Terhadap Sifat Kemagnetan Barium M-hexaferrite (BaFe12-xZnxO19) Dengan Ion Doping Zn. Jurnal Sains Dan Seni ITS. No. 1. Hal: 25-29

[2] Ramli, I,. Saidah, I, N,. Findah, R, S,. \& Zainuri, M. 2012. Pengaruh Variasi $\mathrm{Ph}$ Pelarut Hcl Pada Sintesis Barium M-Heksaferit Dengan Doping Zn (BaFe11,4Zn0,6O19) Menggunakan Metode Kopresipitasi. Makalah disajikan pada Seminar Nasional Fisika Terapan III Universitas Airlangga, Surabaya, 15 September

[3] Hasanah, E, Budi, A, S,. Adi, W, A,. \& Suguhartono, I. 2012. Analisis Struktur Dan Sifat Magnetik Paduan Magnet Nanokristalin Barium Heksaferit BaFe12O19 Dengan Metode Mechanical Milling. Makalah disajikan pada Seminar Nasional Fisika Terapan III Universitas Airlangga, Surabaya,15 September

[4] Saidah, I.N dan Zainuri, M. 2012. Pengaruh Variasi pH Pelarut HCl Pada Sintesis Barium M-Heksaferit Dengan Doping Zn (BaFe11,4Zn0,6O19) Menggunakan Metode Kopresipitasi. Jurnal Sains Dan Seni ITS. 1: 41-46

[5] Yuliana, D. 2011. Pengaruh Variasi Temperatur Terhadap Pembentukan Struktur Kristal Barium M-Heksaferit Tersubstitusi Ion Dopan Zn. Makalah disajikan pada Seminar Nasional Pendidikan, dan Penerapan MIPA, Surabaya, 14 Mei

[6] Af'idah, N,. Indahnia,. E,. \& Darminto. 2011. Sintesis Barium M-Heksaferit
BaFe12O19 dengan Variasi Temperatur Kalsinasi. Makalah disajikan pada Seminar Nasional Pascasarjana XI - ITS, Surabaya, 27 Juni

[7] Kanagesan, S., Jesurania, S., Velmuragan, R., Kumar, C. dan T. Kalaivania. 2010. Magnetic Hysteresis Property of Barium Hexaferrite Using D-Fructose as a Fuel. Journal of Materials Science and Engineering. 9: 88-92.

[8] Chauhan, C.C., Jotania, R.B,. Jotania, K.R. 2013. Structural properties of cobalt substituted barium hexaferrite nanoparticles prepared by a thermal treatment method. Nanosystems: Physics, Chemistry, Mathematics. 4: 363-369.

[9] Temuujin, J., Aoyamaa, M., Sennaa, M,. dkk. 2004. Synthesis of Y-type hexaferrites via a soft mechanochemical route. Journal of Solid State Chemistry. 177: 3903-3908.

[10] Pereira, F.M.M., Junior, C.A.R., Santos, M.R.P., dkk. 2008. Structural and dielectric spectroscopy studies of the M-type barium strontium hexaferrite alloys (BaxSr1-xFe12O19). Jurnal mater science. 19: 627-638

[11] Omprakesh, S., Parveen, A., dan Naik, P.S. 2012. Synthesis, Characterization and DC Conductivity of Barium Hexaferrite. International Journal of Scientific and Engineering Research. 3: 1-4.

[12] Kaur, T dan Srivastava, A.K. 2013. Effect of pH on Magnetic Properties of Doped Barium Hexaferrite. International Journal of Research in Mechanical Engineering \& Technology. 3: 171-173.

[13] Pangga, D,. \& Zainuri, M. 2012. Pengaruh Substitusi Ion Dopan Co/Zn Terhadap Struktur Kristal Barium M-Hexaferrite (BaFe12O19). Tesis. Institut Teknologi Sepuluh November

[14] Silvia, L. 2013. Pengaruh Ion Doping Zn pada Sifat Kemagnetan Barium MHeksaferit BaFe12-xZnxO19 berbasis Pasir Besi Tulungagung. Jurnal Fisika Dan Aplikasinya. No: 9. Hal: 121-124 